\title{
Retraction Note to: Theoretical study of the fragmentation of ionized benzophenone
}

\author{
Noura Khemiri $^{1}$ (D) Manef Abderrabba $^{1} \cdot$ Sabri Messaoudi ${ }^{1}$
}

Published online: 2 March 2019

(C) Springer-Verlag GmbH Germany, part of Springer Nature 2019

Retraction Note to: Journal of Molecular Modeling (2018) 24: 272 https://doi.org/10.1007/s00894-018-3766-9

The authors have retracted this article [1] due to an error in obtaining permission to use the data generated at the Synchrotron SOLEIL. All authors agree to this retraction.

[1] Khemiri, N., Abderrabba, M. \& Messaoudi, S. J Mol Model (2018) 24: 272. https://doi.org/10.1007/s00894-018$3766-9$

Publisher's note Springer Nature remains neutral with regard to jurisdictional claims in published maps and institutional affiliations.

The original version of the original article can be found at https://doi.org/ 10.1007/s00894-018-3766-9

\footnotetext{
Noura Khemiri

khemiri.noura58@gmail.com

1 Laboratoire Matériaux, Molécules et Applications, Institut Préparatoire aux Etudes Scientifiques et Techniques, La Marsa, Université de Carthage, Carthage, Tunisie
} 